\title{
Effect of households' dietary knowledge on local (ofada) rice consumption in southwest Nigeria
}

\author{
A. O. Ogunleke* and Lloyd J. S. Baiyegunhi
}

\begin{abstract}
An understanding of dietary knowledge will most likely inform the consumption of healthy foods. Studies have shown that local (ofada) rice is superior to other rice brands in terms of protein and minerals crucial for overall mental and physical well-being. This study, therefore, examined the effect of households' dietary knowledge on the consumption of local (ofada) rice, using a simultaneous equation system that accommodates censored dependent variable and continuous endogenous dietary knowledge. The study used survey data from 600 rice consumers' households in southwest Nigeria and hypothesized that dietary knowledge affects the consumption of local (ofada) rice. The results revealed that dietary knowledge is significantly influenced by factors such as being a household meal planner and presence of household member(s) on a special diet. Dietary knowledge, as hypothesized, was found to positively influence the consumption of local (ofada) rice, as were some sociodemographic variables. The study recommends that effective dietary education about health and other benefits of consuming local (ofada) rice should be developed to promote its consumption in Nigerians' diets.
\end{abstract}

Keywords: Local (ofada) rice, Simultaneous equation system, Dietary knowledge, Southwest Nigeria

\section{Introduction}

The importance of good nutrition for healthy living cannot be overemphasized. This is necessary, given that in recent times, the high rate of health risks associated with poor diets and eating habits is on the increase [1]. Dietary knowledge is important in understanding food safety and hazards, and in reducing the prevalence of noncommunicable diseases [2]. Thus, a positive attitude towards dietary information and proper practices may help to control and prevent further complication of some non-communicable diseases [3]. Food-borne diseases (such as diabetes mellitus, hypertension, obesity, and cancer) afflict more than $30 \%$ of the world's population annually, due to inadequate dietary knowledge $[4,5]$. Majority of people consume food without adequate knowledge of its nutritional components and the specific ration needed in the nutrient. Dietary knowledge is sacrosanct and germane to healthy living; it is one of the crucial factors in the promotion of healthy eating

\footnotetext{
* Correspondence: ayoogunleke@yahoo.com

SAEES - Discipline of Agricultural Economics, University of KwaZulu-Natal, P. Bag X01, Scottsville, Pietermaritzburg 3209, South Africa
}

cultures aimed at maintaining suitable body weight and in promoting healthy living through identification of foods that are protective or detrimental to health [6]. Adebamowo and World Health Organization (WHO) [7, 8] posited that lack of dietary knowledge is one of the major reason households spend money on unhealthy foods by opting for foods that are high in fats and sugar content over fresh fruits, vegetables, and dietary fiber such as whole grains.

Several studies have linked dietary knowledge to diet quality of children, old people, and female household heads [9]. It has also been linked to consumption of foods such as meat [10], eggs [11], fruits and vegetables [12], fat-modified foods [13], grains [14], and other numerous list of food groups consumed at and away from home [15].

Ideally, an understanding of dietary knowledge will most likely inform consumption of healthy foods [16]. Chokshi [17] showed the disparities in diet and health between rich and poor people in the USA and asserted that wealthier people are healthier because they choose better diets, are well informed about their diets, and

(C) The Author(s). 2019 Open Access This article is distributed under the terms of the Creative Commons Attribution 4.0 International License (http://creativecommons.org/licenses/by/4.0/), which permits unrestricted use, distribution, and 
more physically active. Consequently, it is difficult to separate the effect of dietary knowledge from those of any other behavioral factor when it comes to food consumption. However, this might not be the case in Nigeria; people who are better educated may have greater dietary knowledge, yet socioeconomic reasons might influence their food consumption more than dietary knowledge [7].

Extant literature has revealed that the choice of foods that contribute to dietary energy intake has been changing in different parts of the world [8]. For instance, rice is the most consumed staple food and has become the main source of dietary energy among Nigeria households $[7,18]$. United States Agency for International Development [19] reported that preference for long grain, polished, and destoned imported rice is associated with urban areas where income is high, while locally milled rice is consumed widely among poor households in the rice-producing rural areas. Although Nigeria is the largest producer of rice in West Africa, most of the rice varieties consumed in the country are imported from countries like Thailand, Brazil, India, USA, and the United Arab Emirates [20]. However, statistics have shown that Nigeria produced approximately 2.6 million metric tons of milled rice and imported about 3.8 million metric tons between 2014 and 2015 [19].

Consumption of foreign rice brand is common among many Nigerians compared with the local varieties such as "ofada" and "abakaliki" rice produced in the country. Local (ofada) rice as averred by Ologbon et al. [21] is a rice variety named after a town called "Ofada" in Ogun State, southwest Nigeria (Fig. 1), where it was first cultivated and processed. Local (ofada) rice tends to be brown having been dehulled once and unpolished. It is, however, more nutritious and provides a greater amount of nutrients and other protective substances than the imported white rice, which has been milled several times to remove the husk, bran, and germ leaving mostly the starchy endosperm [22].

Local (ofada) rice is assumed to have been first brought to Nigeria during the World War One (WWI) and believed to be blend of Oryza glaberrima (African rice) as well as the more common Oryza sativa (Asian rice) [23]. Local (ofada) rice is an upland rice grown on free drawing soil where the water table is permanently below the roots of the rice plant [24]. It is more difficult to mill and polish with some of the rice bran left on the grain. The fact that the

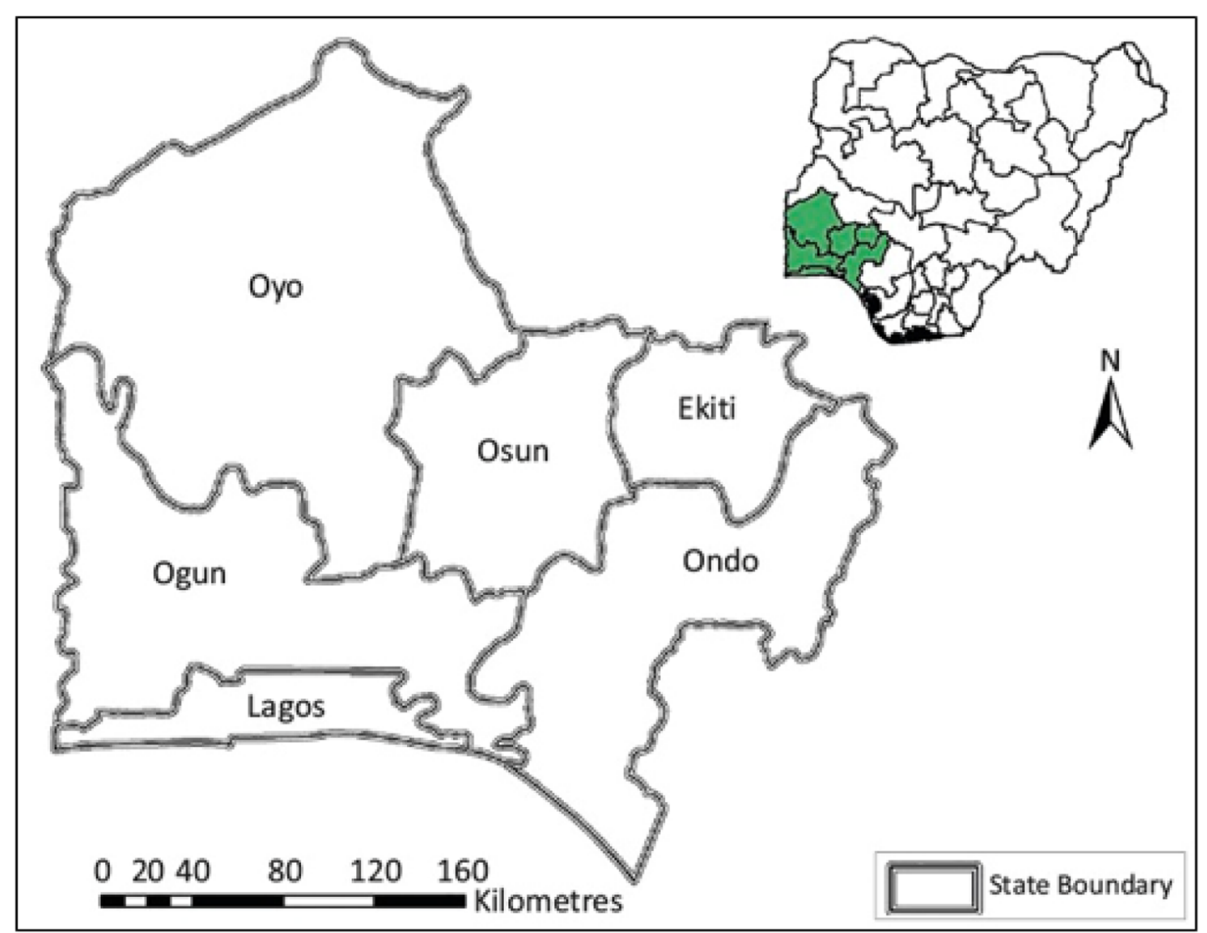

Fig. 1 Map showing the location of states within the southwest zone in Nigeria where local (ofada) rice is predominant both in production and consumption. The study was conducted in the southwest region of Nigeria. The region is one out of six geopolitical zones in the country. Southwest region lies between longitude $2^{\circ} 31^{1}$ and $6^{\circ} 00^{1}$ east, and latitude $6^{\circ} 21^{1}$ and $8^{\circ} 37^{1} \mathrm{~N}$, and has total land area about $77,818 \mathrm{~km}{ }^{2}$. It shares boundaries in the west, south, east, and north by the Republic of Benin, Gulf of Guinea, Edo and Delta States, and Kwara and Kogi States respectively. Southwest Nigeria climate is tropical in nature and its experiences both raining and dry seasons. (Retrieved

from https://en.wikipedia.org/w/index.php?title=South_West_(Nigeria)\&oldid=911584164) 
rice is unrefined strengthens the flavor and makes it nutritionally superior to polished white rice [21]. Local (ofada) rice is often very aromatic and known for high swelling ability when cooked [25]. Consumers in southwest Nigeria have great concern and attachment for this domestically produced local rice "Ofada." This concern was proven not to be based on economic benefits, rather it is a reflection of indigenous connectivity of the society wherein local (ofada) rice is found which can be established on the ethnic and cultural attraction (heritage), as reflected in the way and manner of processing, dishing, and satiety value obtained at consumption of this brand of local rice [24]. Traditionally, processing of local (ofada) rice paddy involves three stages of treatment: soaking, parboiling, and drying and sometimes processed using fermentation, which adds an aromatic quality to the product [26].

Local (ofada) rice is typically priced higher compared with other available types of rice, and it has been regarded as a sign of status symbolism by some consumers $[21,26]$. Culturally, prior to this time, people believed that local (ofada) rice should be served during festive period and special occasions such as wedding ceremony and birthday parties due to the rigor involved in the preparation. It is now an everyday type of food for most Nigerians, especially in the southwest part of the country as a result of tremendous improvement in the processing technology [26]. Local (ofada) rice is traditionally served in an "uma leaf" (Thaumatococcus danielli) (Fig. 2), with a sauce of "Atarodo" (spicy) and "Tatase" (sweet) pepper, onion, locust beans, palm oil, and assorted meat [24]. It is also often served along with a vegetable stew that may contain locust beans as an ingredient and also with "Ayamase" a designer stew or "Obe-ata-iru," both specially prepared for ofada rice consumption [24]. The mode of preparation, serving, and emotional value obtained in eating local (ofada) rice is traced to its indigenousness that connects people to their cultural heritage and food habit [25].

Most Nigerians consume imported white rice regularly at lunch- or dinnertime [18]. Estimates from the West Africa Rice Development Association (WARDA) showed that per capita rice consumption in Nigeria nearly doubled between 1980s and 2006, growing from 15.4 to $25.4 \mathrm{~kg} /$ year [20]. Aune [27] affirmed that intake of imported white rice is associated with increased risk of non-communicable diseases in different populations, while higher dietary intake of brown rice or its substitution for imported white rice in the diet may reduce the risk of these diseases. To buttress the above assertion, some intervention studies found that substituting brown rice for white rice helped reduce glycemic response [28].

Previous studies such as Osaretin et al. [29] have established that local (ofada) rice contains higher proteins at raw, cooked, and soaked states compared with imported rice. It also has a rough surface, more phosphorous, and fiber that help in reducing risk of bowel disorder and constipation. It also contains an appreciable amount of selenium, which has been found to be effective in combating colon and breast cancer [26, 30]. Local (ofada) rice brand is also a good source of minerals, which contribute to the recommended dietary allowance [29]. According to Champe and Harvey [31], these minerals are crucial for overall mental and physical wellbeing. Despite these nutritional advantages, rice consumers in Nigeria tend to consume imported polished rice varieties over the local (ofada) variety. According to Adebamowo et al. [7], lack of dietary knowledge is a limiting factor affecting the choice of food to consume in Nigeria. Low consumption of local (ofada) rice variety is likely due to the lack of information regarding its nutritive values. Although information is available about production and processing of local (ofada) rice, relatively little is known about the impact of
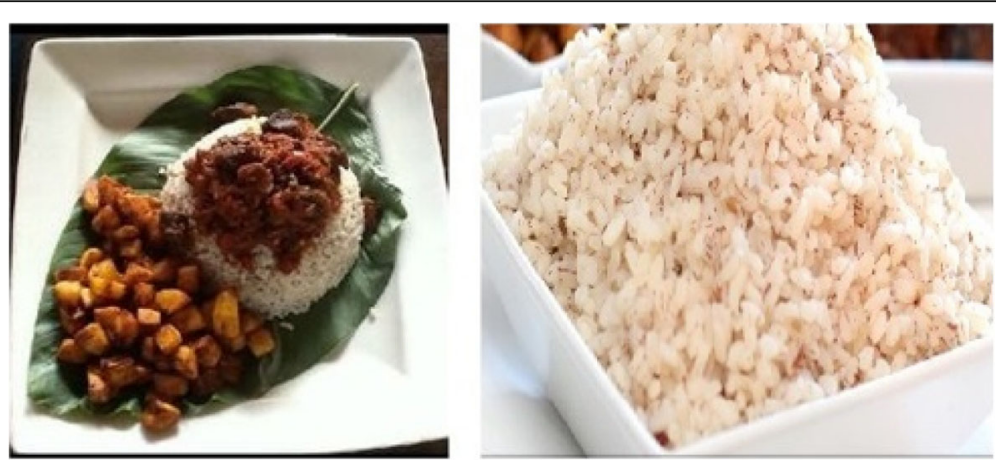

Fig. 2 Showing local (Ofada) rice served in traditional style with fried plantain and beef. It is traditionally served in an "uma leaf" (Thaumatococcus danielli), as shown in the picture, with a sauce of "Atarodo" (spicy) and "Tatase" (sweet) pepper, onion, locust beans, palm oil, and assorted meat. It is also often served along with a vegetable stew that may contain locust beans as an ingredient and also with "Ayamase" a designer stew of "Obe-ata-iru," both specially prepared for ofada rice consumption. (Retrieved from https://en.m.wikipedia.org) 
dietary knowledge on its consumption. This study, therefore, examines the effect of households' dietary knowledge on the consumption of local (ofada) rice.

\section{Conceptual and theoretical framework}

This study is built on a standard model influenced by Becker and Grossman [32, 33] of consumer demand that assumes individuals gain utility from the foods they eat $(F)$, quantity consumed $(y)$, and a composite non-food item $(N)$. In this model, quantity of rice consumed is assumed to be determined by some exogenous factors $(\phi)$ which include age, gender, and household size. It is also specified that rice consumption can be affected be some endogenous factors $(\alpha)$ such as being a household meal planner and presence of household member on special diet by the way of dietary knowledge $(\eta)$. This study is thus based on the assumption that individual's choices are constrained by prices $(P)$ and income $(I)$. As such, it is assumed that an individual $(i)$ maximizes utility subject to a budget constraint and dietary knowledge. The derived consumption function for rice is expressed in Eq. (1) as:

$$
y_{i}=f\left(P_{i} I_{i} \phi_{i} \eta_{i}\left(\alpha_{i}\right)\right) .
$$

where $y_{i}$ is the quantity of rice consumed, $P_{i}$ is the price of the commodity, $I_{i}$ is household income, $\phi_{i}$ are the exogenous factors influencing consumption, $\alpha_{i}$ represents factors that are determined by dietary knowledge, and $\eta_{i}$ household dietary knowledge.

The common problem with consumption studies is that food consumption data from cross-sectional surveys usually contain notable proportion of observations not consuming certain food items [34]. Thus, statistical procedures not accommodating censoring or endogeneity produced bias estimates [35]. In this study, some respondents report zero consumption of local (ofada) rice. The issue of zero consumption may be due to lack of dietary knowledge of respondents about local (ofada) rice. Estimating consumption of local (ofada) rice variety without accounting for respondents with zero consumption will yield inconsistent parameter estimates [16]. This is the issue of censored dependent variable. More so, dietary knowledge included in the consumption equation is potentially endogenous and this creates a statistical problem of endogeneity, which indicates that an independent variable included in the model is potentially a choice variable, and variables can be jointly determined which as a result leads to correlation between the unobservable and the disturbance term [35]. According to Ormond [35], the possible endogeneity problem has two implications: first, the parameter estimate will be biased and inconsistent and the model will fit too well, and this will make the magnitude of the parameter estimates unreliable, as the measures of goodness of fit and secondly, it makes interpretation of the parameter estimates difficult.

The most common way to deal with the problem of endogeneity is with the use of instrumental variables (IV) [34]. An instrument is a proxy for the endogenous explanatory variable $X$ that is highly correlated with other explanatory variables but is uncorrelated with the error term of the consumption equation [36]. Therefore, to explicitly account for endogeneity, the instrumental variable tobit (ivtobit) was adopted to estimate the simultaneous equation. The instrumental variable tobit (ivtobit) is a hybrid tobit model, where one or more of the regressor is endogenously determined. Maximum likelihood estimate (MLE) was used to estimate the parameters because it assumed that the endogenous regressor is continuous as the case of dietary knowledge in this study. The criteria for overidentification and endogeneity for MLE were met as in the case of instrumental variable estimation for which exclusion condition is needed for identification.

Choosing instrument for correcting endogeneity might be problematic [37]; this study follows [16] who hypothesized that education, a member of household on a special diet, and being a household meal planner, will not influence consumption directly. Thus, these variables were used in the knowledge equation, though they may have indirect impact on consumption by way of dietary knowledge equation. It is pre-empting that people with these characteristics are more likely to have better and adequate knowledge of what they consume.

\section{Methodology \\ Model specification}

Based on the above and in line with econometric model used by Lin and Yen and Yen et al. [14, 16], a simultaneous equation system was developed in which consumption variables $\left(y_{i}\right)$ for local (ofada) rice was set to zero (censored) with endogenous continuous variable for dietary knowledge $\left(d_{0}\right)$ included among the explanatory variables for the consumption equation. The endogenous regressor, dietary knowledge $\left(d_{0}\right)$ equation, is specified as:

$$
d_{0}=z^{\prime} \alpha+\mu_{0}
$$

The censored equations for local (ofada) rice $y_{i}$ can be expressed as:

$$
y_{i}=\max \left(0, x^{\prime} \beta_{i}+\gamma_{i} d_{0}+v_{i}\right)
$$

where $d_{0}$ is the dietary knowledge of the respondent, $y_{i}$ is the quantity of local (ofada) rice consumed, $Z$ and $x$ are the vectors of exogenous variables, $\alpha$ and $\beta_{i}$ are the 
vectors of parameters, $\gamma_{\mathrm{i}}$ is the scalar parameters, and $\mu_{0}$ and $v_{i}$ are the error terms.

Such that $\left[\mu_{0}, v^{\prime}\right] \equiv\left[\mu_{0}, v_{1}, \ldots, v_{m}\right]^{\prime} \mu 0,^{\prime} \equiv \mu 0, v 1, \ldots, v m^{\prime}$ are distributed as $(\mathrm{m}+1)$-variate normal $N(0, \Sigma)$, with a finite covariance

$$
\sum=\left[\begin{array}{ll}
\sum_{\sigma_{0}^{2}} & \sum_{12} \\
\sum_{21} & \sum_{22}
\end{array}\right],
$$

Such that $\sum_{\sigma_{0}^{2}}$ is a scaler, $\Sigma_{21}=\Sigma_{12}$ is $\mathrm{m} \times 1 \mathrm{~m} \times 1$, and $\Sigma_{22}$ is $\mathrm{m} \times 1$. This model is like the simultaneous equation systems of Smith et al. [38] with only one censored equation as Eq. (2). Also, the logarithmic transformation on $y_{i}$ and the presence of the endogenous regressor, $d_{0}$, the censored system (2) is in line with model specified by Yem et al. [16] for cross-sectional data with constant prices as in the present study. This ivtobit procedure produces reliable and efficient parameter estimates, which permits an appropriate test of endogeneity of the dietary knowledge variable through the statistical significance of the augmented regressor $\widehat{u_{0}}$ in the censored equation in Eq. (2).

\section{The study area and method of data collection}

This study was carried out in southwestern part of Nigeria. The region is one of the six geopolitical zones in Nigeria and is made up of six states, which are the following: Lagos, Ogun, Oyo, Osun, Ondo, and Ekiti States. The data used for this study were collected from a survey of 600 households conducted from three States (Lagos, Ogun, and Osun) purposively chosen because of the increasing level of local (ofada) rice production and its presence in the local markets across the areas. A multistage sampling technique was employed to select the respondents in the study area. Firstly, the study purposively selected three states, namely Lagos, Osun, and Ogun because of the predominance of local (ofada) rice farmers in the states and its presence in various markets across the states. This same technique was adopted in the second stage to select two local government areas (LGAs) from each selected state. The third stage involved a random selection of two wards each from the two LGAs selected in the second stage based on the lucky-dip approach $[39,40]$, while the last stage involved a random selection of 50 rice consuming households in each of the two wards which sum up to 600 respondents that was used for the study.

Food consumption and expenditure data of different households were collected and used for the study. This was done using well-structured questionnaire to collect required information from heads of households or their representatives where the heads were not available. The information sought includes the households' rice consumption data and their demographic and socioeconomic characteristics. Rice consumption information collected includes brand of rice consumed, frequency of consumption, quantity consumed per month, price per kilogram, and expenditure on rice consumed by the households during the sample period. In relation to dietary knowledge, respondents were asked to rate the importance of adding salt or sodium to food in moderation and preferring a diet low in saturated fat. Specifically, they were asked whether they were aware of the nutritional superiority of local (ofada) rice to imported rice in terms of fiber, protein and phosphorous contents, and low moisture content among many other nutritional values in addition to better taste.

\section{Definition of variables}

Dependent variables The dependent variable in knowledge equation used in this study is constructed from answers to two sets of questions: general dietary guidance and nutritional awareness specific to rice consumption. The sum of the correct answers to the number of questions asked was used to construct the dietary knowledge variable. On the other hand, the dependent variable for consumption equation is the quantity of local (ofada) rice consumed, measured in kilogram.

Independent variables The independent variables for rice consumption include household income, household size, gender, age, location (Lagos, Ogun, and Osun States), price, consumption place, dietary knowledge, level of education (measured in year), sources of dietary information, and occupation. The study hypothesized that dietary knowledge affects local (ofada) rice consumption, and this dietary knowledge variable is endogenized in the system of demand equations. Therefore, in addition to aforementioned variables, dietary knowledge is assumed to be affected by being a household meal planner and if any family member(s) is/are on special diet.

\section{Results and discussions}

\section{Descriptive statistics}

The sample descriptive statistics for all variables are presented in Table 1 . The average quantity of local (ofada) rice consumed by a household ranges from 6.19 to $25.8 \mathrm{~kg}$, while that of imported rice ranges from 5.74 to $22.14 \mathrm{~kg}$ per month. Individual households consumed a minimum of $37.03 \mathrm{~kg}$ and maximum of $58.9 \mathrm{~kg}$ of both rice varieties per month with their income ranging from

$38,265.35$ to $157,224.71$. The dietary knowledge score registered an average of 4.67 (out of 10). 
Table 1 Definition and descriptive statistics of the variables used for the study $(n=600)$

\begin{tabular}{|c|c|c|}
\hline Variable & Definition & Mean \\
\hline Dependent variable & Quantity of rice consumed $(\mathrm{Kg})$ & \\
\hline Quantity of local (Ofada) rice & Local (ofada) rice consumed per month (kg) & $15.98(9.79)$ \\
\hline \multicolumn{3}{|l|}{ Endogenous variable } \\
\hline Dietary Knowledge Score & Sum of 10 binary indicators covering respondent's dietary knowledge & $4.67(0.24)$ \\
\hline \multicolumn{3}{|l|}{ Continuous variables } \\
\hline Income per month & Household income per month ( ) & $97,745.03(59,479.68)$ \\
\hline Household size & Number of people in the household & $0.52(0.50)$ \\
\hline \multicolumn{3}{|l|}{ Discrete (binary) } \\
\hline Gender dummy, male $=1$, female $=0$ & Male or female & 3.25 \\
\hline Age $20-30$ & Respondent between age 20-30 & 0.22 \\
\hline Age $31-40$ & Respondent between age 31-40 & 0.40 \\
\hline Age $41-50$ & Respondent between age 41-50 & 0.30 \\
\hline Age above 50 & Respondent age 51 and above & 0.12 \\
\hline Personal & Personal source of information is the information gained through personal experience & 0.31 \\
\hline Family member & Information from family member & 0.25 \\
\hline Associates & Information from associates & 0.09 \\
\hline Nutritionist & Information from nutritionist & 0.15 \\
\hline Health care professionals & Information from health care professionals & 0.18 \\
\hline Household meal planner & Meal planner is the one who takes time to plan the meals for the household. & 0.64 \\
\hline Member on special diet & Whether any household member is on special Diet & 0.06 \\
\hline Farming & Farming occupation & 0.09 \\
\hline Civil servant & Government worker & 0.61 \\
\hline Artisan & Artisans are workers in a skilled trade & 0.22 \\
\hline Lagos & Resides in Lagos State & 0.41 \\
\hline Ogun & Resides in Ogun State & 0.42 \\
\hline Osun & Resides in Osun State & 0.41 \\
\hline Home & Rice consumed at home & 0.78 \\
\hline Away & Rice consumed away from home & 0.28 \\
\hline No formal education & No formal education & 0.05 \\
\hline Adult literacy & Adult education & 0.05 \\
\hline Primary & Primary education & 0.04 \\
\hline Junior secondary & Junior secondary education & 0.04 \\
\hline Senior secondary & Senior secondary education & 0.10 \\
\hline Tertiary & Tertiary education & 0.61 \\
\hline
\end{tabular}

Standard deviation in parentheses

\section{Maximum likelihood estimates for dietary knowledge equation}

The parameter estimates and standard error for the dietary knowledge equation are presented in Table 2. The result shows that gender, being a household meal planner, presence of household member(s) on special diet, and respondents residing in Ogun and Osun States have significant influence on dietary knowledge. Given the normalization in the measurement model, a positive coefficient in the knowledge equation indicates the corresponding variable and increases the probability that a person is more aware of the nutritional contents of rice brand she/he consumes.

The estimates (Table 2) show that coefficient of being a household meal planner is statistically significant and positively affects dietary knowledge. This result is expected, as it was forestalled that people in such position should be more aware of food they consume. The plausible explanations for this may be that there is adequate information regarding the dietary contents of local 
Table 2 Parameter estimates for dietary knowledge equation using maximum likelihood estimates (MLE)

\begin{tabular}{|c|c|c|c|}
\hline Variables & Coefficient & Robust standard error & $p$ value \\
\hline Age & -0.003 & 0.002 & 0.104 \\
\hline Year of education & 0.008 & 0.014 & 0.558 \\
\hline Gender (female = 1) & $0.395^{* * *}$ & 0.057 & 0.000 \\
\hline Household meal determinant & $0.069^{*}$ & 0.040 & 0.089 \\
\hline Member on special diet & $1.800^{* * *}$ & 0.085 & 0.000 \\
\hline \multicolumn{4}{|l|}{ Occupation } \\
\hline Farming & -0.057 & 0.074 & 0.448 \\
\hline Civil servant & 0.058 & 0.050 & 0.252 \\
\hline Artisan & 0.091 & 0.065 & 0.165 \\
\hline \multicolumn{4}{|l|}{ Location/state } \\
\hline Lagos & -0.006 & 0.050 & 0.903 \\
\hline Ogun & $-0.093^{*}$ & 0.048 & 0.055 \\
\hline Osun & $0.194^{* *}$ & 0.048 & 0.000 \\
\hline \multicolumn{4}{|l|}{ Sources of information } \\
\hline Personal & 0.093 & 0.057 & 0.101 \\
\hline Family member & 0.071 & 0.052 & 0.169 \\
\hline Associates & 0.026 & 0.067 & 0.693 \\
\hline Health care professionals & 0.073 & 0.061 & 0.230 \\
\hline Constant & 0.852 & 0.113 & 0.000 \\
\hline Number of observations & 600 & & \\
\hline$R^{2}$ & 0.504 & & \\
\hline$F(15,585)$ & $33.66^{* *}$ & & \\
\hline$p$ value & 0.000 & & \\
\hline
\end{tabular}

$*, * *$, and ${ }^{* * *}$ denote significance at $10 \%, 5 \%$, and $1 \%$ level, respectively

(ofada) rice, and/or the simplicity of the available information written on the labels in case of those consuming packaged ones [41]. Another likely reason could be that household meal planners are using dietary information effectively when making decisions on food to consume [42].

Coefficient of presence of household member(s) on special diet is statistically significant and positively correlates with dietary knowledge. This shows that households with such individuals are more aware of the nutrients benefits associated with the consumption of local (ofada) rice. The reason could be that, it is expected that consumers who follow a special diet should have knowledge of food to consume, as they are more informed about the relationship between diet and health. Also, it could be as a result of adequate dietary counseling provided to the participants when they are diagnosed with a specific medical condition [42, 43].

The coefficient of gender is significant and positively affects dietary knowledge. This implies that women on the average are more knowledgeable about nutrient benefits associated with local (ofada) rice consumption. The possible explanations for this could be as a result of women being more apt to receive formal and informal education on food preparation and relevant diet information [44]. Also, the traditional role of female consumers as the gatekeeper of household food choices and purchases could motivate their interest to have the knowledge of food [43]. In addition, their responsibility towards the well-being of their family also creates an awareness of the nutritional content of food [42].

The coefficient of location of Osun exhibited a positive and significant effect on dietary knowledge. The result implies that regional differences exist as regards households' knowledge of nutrition and health benefits of local (ofada) rice. This means that respondents in Osun State are more knowledgeable about nutrition and health benefits of local (ofada) rice compared with Ogun State. This is evident with the coefficient of Ogun State having negative and statistically significant correlation with dietary knowledge. A likely explanation for this is that majority of respondents in Ogun State are into farming and probably had not received formal education that is required to make a significant difference in accumulating such information regarding the health benefits associated with local (ofada) rice. As opined by Lin and Yen 
and Yen et al. [14, 16], in their separate studies that a larger percentage of respondents with educational attainment were able to answer dietary knowledge questions correctly.

\section{Estimates for local (ofada) rice variety consumption with endogenous dietary knowledge}

The dietary knowledge and consumption equation error correlation gives room for endogeneity of dietary knowledge in the corresponding consumption equation [16]. As a result of the significance of error correlations, the hypothesis of exogenous dietary knowledge is accepted at $5 \%$ level for local (ofada) rice. Test results for endogeneity and simultaneity are confirmed by likelihood ratio tests, with $p$ values $<0.0001$ for a censored equation system with exogenous dietary knowledge variable.
Table 3 presents the results of estimated parameters for consumption equations with endogenous variable. Thirteen variables were statistically significant in influencing the consumption of local (ofada) rice. These variables include income, dietary knowledge, year of education, gender, price, country of origin, occupation (farming and artisan), Lagos location, and source of information (personal, family member, associate, and health care professional).

The coefficient of income is negative and statistically significant in influencing consumption of local (ofada) rice. According to classical microeconomics, demand is a positive function of income, for normal goods. That is, increase in income should bring about increase in the demand for a product. However, in this study, the reverse is the case. As income increases, consumption of local (ofada) rice decreases. It is no surprise that the

Table 3 Parameter estimates for local (ofada) rice consumption with endogenous dietary knowledge

\begin{tabular}{|c|c|c|c|}
\hline Variables & Coefficient & Robust standard error & $p$ value \\
\hline Income & $-4.530^{*}$ & 2.413 & 0.061 \\
\hline Household size & 0.111 & 0.743 & 0.882 \\
\hline Dietary knowledge & $3.708^{* *}$ & 1.534 & 0.016 \\
\hline Year of education & $0.650^{* *}$ & 0.281 & 0.021 \\
\hline Gender (female $=1$ ) & $0.062^{*}$ & 0.036 & 0.085 \\
\hline Price & $5.434^{* *}$ & 2.264 & 0.016 \\
\hline Country of origin & $11.189^{* * *}$ & 2.293 & 0.000 \\
\hline Household meal determinant & -0.112 & 0.855 & 0.896 \\
\hline Member on special diet & 1.008 & 0.774 & 0.193 \\
\hline \multicolumn{4}{|l|}{ Occupation } \\
\hline Farming & $-2.567^{* *}$ & 1.240 & 0.038 \\
\hline Civil servant & -0.585 & 1.003 & 0.560 \\
\hline Artisan & $-3.747^{* * *}$ & 1.227 & 0.002 \\
\hline \multicolumn{4}{|l|}{ Location/state } \\
\hline Lagos & $3.681^{* * *}$ & 1.137 & 0.001 \\
\hline Ogun & -0.169 & 0.911 & 0.853 \\
\hline Osun & -1.070 & 1.165 & 0.359 \\
\hline \multicolumn{4}{|l|}{ Sources of information } \\
\hline Personal & $4.004^{* * *}$ & 1.122 & 0.000 \\
\hline Family member & $-4.207^{* * *}$ & 0.921 & 0.000 \\
\hline Associates & $-2.353^{* *}$ & 1.019 & 0.021 \\
\hline Health care professionals & $7.479^{* * *}$ & 1.636 & 0.000 \\
\hline Constant & 13.108 & 10.639 & 0.218 \\
\hline Number of observation & 600 & & \\
\hline$x^{2}(1)$ & $5.580^{* *}$ & & \\
\hline$p$ value & 0.018 & & \\
\hline Wald $x^{2}(20)$ & $158.81^{* * *}$ & & \\
\hline$p$ value & 0.0000 & & \\
\hline
\end{tabular}


study found an inverse relationship between consumption and income; generally, the tastes of high-income earners are most likely to orient towards foreign goods than local goods. The plausible explanations for this could be that households with higher income would probably want to consume imported rice brands that are easy to prepare than local (ofada) rice, which has been found difficult to prepare, due to the experience that local (ofada) rice is "dirty" because of the presence of foreign matters. This agrees with Wardle et al. [45], who reported that people from higher socioeconomic and educational status tend to consume foods which are more luxurious and easier to prepare than foods consumed by those of lower socioeconomic and educational status.

Coefficient of dietary knowledge is statistically significant and positively influences consumption of local (ofada) rice. However, scores from knowledge questions show that respondents did not necessarily have adequate understanding of nutritive value of local (ofada) rice. This result confirms the study of Demont and Ndour [46], who found that nutritional quality and intrinsic cues such as taste are key factors responsible for the consumption of local (ofada) rice unlike imported varieties they consume due to relative ease of preparation. As opined by Gyimah-Brempong et al. and Ayinde et al. $[26,30]$, local (ofada) rice has a rough surface, more phosphorous, and fiber which help in the reduction of the risk of bowel disorder and fighting constipation, and contains an appreciable amount of selenium which has been found to be effective in fighting colon and breast cancer. Osaretin et al. [29] also found that local (ofada) rice variety contains higher proteins at raw, cooked, and soaked states as compared with imported rice.

The coefficient for year of education is positive and statistically significant in influencing the consumption of local (ofada) rice. This implies that additional years of education of respondents will bring about increase in the consumption of local (ofada) rice. This result is expected because education attainment is assumed to have a positive correlation with food consumption. The influence of education on local (ofada) rice consumption could result from the social context, as educated heads of household may want to consume high-quality rice varieties such as local (ofada) rice as a prestige.

The coefficient of gender was positive and significantly influences the consumption of local (ofada) rice. This means that the probability of consuming local (ofada) rice was higher with female-headed households than male-headed households. This is a significant finding considering the core role women play in household food choice and provision as opined by the Pro-poor Opportunities in Commodity and Service Markets Project (PrOpCom) [47]. Thus, it is the significant role of women in the households to put food on the table for the members of their households. This result agrees with study of Tomlins et al. [48] who stated that gender is one of the factors that influence households' consumption of rice.

The price has a positive coefficient and statistically significant in influencing the consumption of local (ofada) rice. This indicates that holding other factors constant, respondents in the study area will be more likely to choose local (ofada) rice even if its price is higher. Thus, increments on the price of local (ofada) rice will not decrease the associated utility level provided by the choice option. The possible explanation could be as a result of the nutritional quality of local (ofada) rice as opined by Gyimah-Brempong et al. and Osaretin et al. [26, 29], that local (ofada) rice is more nutritious than foreign rice, thus influencing its demand.

The coefficient of country of origin is statistically significant and positively influences the consumption of local (ofada) rice. The result suggests that country of origin is a very important factor in household purchasing decisions. This implies that respondents are consuming local (ofada) rice because it is grown and processed in Nigeria. Country of origin has been found to be a key variable explaining consumers' willingness to pay a price premium for a product [49]. The likely reason for this might reflect their concern for domestically produced rice and not for economic benefits. Another reason could result from indigenous connectivity of the society wherein local (ofada) rice is found which can be established on the ethnic and cultural attraction (heritage), as reflected in the way and manner of processing, dishing, and satiety value obtained at consumption of this brand of local rice. This result agrees with many studies such as [47, 48 and 49], who opined that country of origin is an important credence attribute for rice consumption.

The coefficient of occupation (farming and artisan) is negative and statistically significant in influencing the consumption of local (ofada) rice. This implies that respondents that are farmers and artisans are less likely to consume local (ofada) rice. The possible explanation for this could be as a result of high price of local (ofada) rice which is due to the high cost of production as compared with imported rice. Another plausible reason could be that those who are farmers produce for commercial purposes and not for consumption. The result corroborates the study of Gyimah-Brempong et al. [26], who reported that local (ofada) rice is more expensive compared with imported rice. Lagos location coefficient is positive and statistically significant in influencing households' consumption of local (ofada) rice. This implies that Lagos State respondents consume more of local (ofada) rice than respondents in Ogun and Osun 
States. This may be as a result of availability of packaged local (ofada) rice in the supermarkets unlike other locations (in Ogun and Osun States) where most of consumers still buy local (ofada) rice in the open markets.

Personal source of information coefficient is positive and statistically significant in influencing consumption of local (ofada) rice. This can be attributed to individual experience of local (ofada) rice being a nourishing food, with unique taste, pleasant aroma, well processed and packaged, free of foreign matters, and easily available in the market [46]. In addition, information from the health care professionals has positive coefficient and is statistically significant in influencing consumption of local (ofada) rice. This is an indication that the health care professionals are sensitizing people on the benefits of consuming local (ofada) rice and this tends to increase the consumption of the local rice brand (ofada). Empirical evidence suggests that advice provided by nutritionist or health care professionals can improve individuals' dietary behavior and consumption [50]. Coefficients of information from family member and associates are statistically significant and negatively influence the consumption of local (ofada) rice. This means that information from family members and associates decrease the consumption of local (ofada) rice. The likely explanation could be because of their initial premonition that foreign materials are present in the local (ofada) rice variety.

Some variables that affect the dietary knowledge may have both direct and indirect effects on local (ofada) rice consumption. For instance, while being a household's meal planner and presence of household member(s) on special diet do not have direct effect on household's consumption of local (ofada) rice, they have indirect effects by way of dietary knowledge. In addition, Ogun and Osun State locations do not have direct effect on households' consumption of local (ofada) rice; they do have indirect effects by way of dietary knowledge. Furthermore, gender has both direct and indirect (by the way of dietary knowledge) effects on households' consumption of local (ofada) rice.

\section{Conclusion and policy implication}

The study examined the effect of households' dietary knowledge on local (ofada) rice consumption in southwest Nigeria. It was hypothesized in the study that dietary knowledge affects consumption of local (ofada) rice. The result of the study revealed that dietary knowledge and some sociodemographic variables have positive impact on households' consumption of local (ofada) rice, in southwest Nigeria. This shows that better dietary knowledge may increase consumption of local (ofada) rice if given proper attention. Moreover, increased consumption will help reduce prevalence and further complication of non-communicable diseases, since unpolished brown rice such as local (ofada) rice contains mineral elements that help in reducing high risk of these diseases. Furthermore, consumption will lead to increase in local rice production, which will help to reduce the level of importation and reduce government expenditure on rice importation. Therefore, the study recommends that nutritional messages that are appealing about local (ofada) rice variety be introduced through advertisement on different media such as radio, television, and print media. The producers/manufacturers should be encouraged to imprint boldly the nutritional contents of local (ofada) rice on the package in a way that the consumers will understand. Also, government and stakeholders in rice sector should stimulate availability and affordability of well-packaged local (ofada) rice in the market across the region and Nigeria. In addition, an effective dietary education about health and other benefits of consuming local (ofada) rice be developed to promote its consumption in the diets of Nigerians.

\section{Abbreviations \\ FAO: Food and Agriculture Organization; LGAs: Local government areas; MLE: Maximum likelihood estimate; USAID: United States Agency for International Development; WARDA: West Africa Rice Development Association; WHO: World Health Organization; WWl: World War One}

\section{Acknowledgements}

Not applicable

\section{Authors' contributions}

The data analysis and discussion of empirical results were conducted by AOO with technical advice from Prof. LJSB. Both authors read and approved the final manuscript.

\section{Funding}

Not applicable

Availability of data and materials

The data will be available on request.

Ethics approval and consent to participate

Ethical approval was obtained from the Humanities and Social Science Research Ethic Committee of the University of KwaZulu-Natal South Africa. Informed consent was given by all participants.

Consent for publication

Not applicable

Competing interests

The authors declare that they have no competing interests.

Received: 16 September 2019 Accepted: 3 October 2019 Published online: 19 December 2019

\section{References}

1. Capacci S, Mazzocchi M, Shankar B, Brambila MJ, Verbeke W, Pérez-Cueto FJA, Kozioł-Kozakowska A, Piórecka B, Niedzwiedzka B, D'addesa D, Saba A, Turrini A, Aschemann-witzel J, Bech-larsen T, Strand M, Smillie L, Wills J, Traill WB. Policies to promote healthy eating in Europe: a structured review of policies and their effectiveness. Nutr Rev. 2012;70:188-200.

2. Ogbonna DN, Chindah A, Ubani N. Waste management options for health care wastes in Nigeria: a case study of Port Harcourt hospitals. J Public Health Epidemiol. 2012;4(6):156-69. 
3. Wang $H$, Song Z, Zhu YB, Wen Y. Nutritional and eating education improves knowledge and practice of patients with type 2 diabetes concerning dietary intake and blood glucose control in an outlying city of China. Public Health Nutr. 2014;17(10):2351-8. https://doi.org/10.1017/\$1368980013002735.

4. World Health Organization. 10 Facts on Obesity 2010. http://www.who.int/ features/factfiles/obesity/facts/en/index1.html.

5. Food and Agriculture Organization (FAO). The hunger report (The State of Food Insecurity in the World), SOFI, 2010.http://www.fao.org/publications/ sofi/2010/en.

6. Bano A, Afzal M, Sarwar H, Waqas A, Kousar S, Gulzar S. Dietary knowledge attitude and practices of diabetes patients at services hospital Lahore. Int $J$ Appl Sci Biotechnol. 2017;5(2):227-36. https://doi.org/10.3126/ijasbt.v5i2. 17625.

7. Adebamowo SN, Eseyin O, Yilme S, Adeyemi D, Willett WC, Hu FB, Spiegelman D, Adebamowo CA. The global nutrition epidemiologic transition initiative. A mixed-methods study on acceptability, tolerability, and substitution of brown rice for white rice to lower blood glucose levels among Nigerian adults. Front Nutr. 2017;4:33. https://doi.org/10.3389/fnut. 2017.00033.

8. World Health Organization (WHO). Global Action Plan for the Prevention and Control of Non-Communicable Diseases, 2013-2020. Geneva: WHO Press; 2013. p. 1-22.

9. Bloom I, Lawrence W, Barker M, Baird J, Dennison E, Sayer AA, Cooper C, Robinson S. What influences diet quality in older people? A qualitative study among community-dwelling older adults from the Hertfordshire cohort study, UK. Public Health Nutr. 2017;20(15):2685-93.

10. Beulah $\mathrm{P}$, Hettie CS, Nicolette $\mathrm{H}$. Total and haem iron content lean meat cuts and the contribution to the diet. Food Chem. 2016;193:97-101.

11. Kearney J. Food consumption trends and drivers. Philos T Royal Soc B. 2010; 365(1554):2793-807.

12. Brookie $\mathrm{KL}$, Best $\mathrm{Gl}$, Conner TS. Intake of raw fruits and vegetables is associated with better mental health than intake of processed fruits and vegetables. Front Psychol. 2018;9:487. https://doi.org/10.3389/fpsyg.2018. 00487.

13. Bawa AS, Anilakumar KR. Genetically modified foods: safety, risks and public concerns-a review. J Food Sci Technol. 2012;50(6):1035-46.

14. Lin B, Yen ST. Consumer knowledge, food label use, and grain consumption in the US. Appl Econ. 2008;40(4):437-48

15. Taillie LS, Afeiche MC, Eldridge AL, Popkin BM. The contribution of at-home and away-from-home food to dietary intake among 2-13-year-old Mexican children. Public Health Nutr. 2016;20(14):2559-68.

16. Yen ST, Lin B, Davis CG. Consumer knowledge and meat consumption at home and away from home. Food Policy. 2008;33:631-9.

17. Chokshi DA. Income, poverty and health inequality. J Am Med Assoc. 2018; 319(13):1312-3. https://doi.org/10.1001/jama.2018.2521.

18. Akarolo-Anthony SN, Odubore FO, Yilme S, Aragbada O, Odonye G, Hu F. Pattern of dietary carbohydrate intake among urbanized adult Nigerians. Int J Food Sci Nutr. 2013;64(3):292-9. https://doi.org/10.3109/09637486.2012. 746290

19. United States Agency for International Development (USAID). Nigeria: Grain and Feed Update, 2014.

20. Cadoni P, Angelucci F. Analysis of incentives and disincentives for rice in Nigeria, vol. 42. Rome: FAO; 2013

21. Ologbon OAC, Ikheloa EE, Akerele EO. Adoption of 'ofada' rice variety and technical efficiency of rice-based production systems in Ogun State, Nigeria. World J Agric Sci. 2012;8(6):624-31.

22. United States Agency for International Development (USAID). Global food security response Nigeria rice study. microREPORT, 2016; \#159.

23. Pro-poor Opportunities in Commodity and Service Markets Project (PropCOm). Definition of ofada rice qualities through varietal identification and testing. Making Nigerian agricultural markets work for the poor, Monograph Series 2007;\#26.

24. Danbaba N, Anounye JC, Gana AS, Abo ME, Ukwungwu MN. Grain quality characteristics of ofada rice (Oryza sativa L.): cooking and eating quality. Int Food Res J. 2011;18:629-34

25. Adekoyeni OO, Fagbemi SA, Ismaila AR. Ofada rice identity, physical qualities and processing technology options for upgrading: a review. Annu Res Rev Biol. 2018:23(2):1-9.

26. Gyimah-Brempong K, Johnson M, Takeshima $H$. The Nigerian rice economy: policy options for transforming production, marketing, and trade, vol. 30 USA: University of Pennsylvania Press; 2016. -31.
27. Aune $D$, Norat $T$, Romundstad $P$, Vatten $L$. Whole grain and refined grain consumption and the risk of type 2 diabetes: a systematic review and doseresponse meta-analysis of cohort studies. Eur J Epidemiol. 2013;28(11):84558. https://doi.org/10.1007/s10654-013-9852-5.

28. Mohan V, Spiegelman D, Sudha V, Gayathri R, Hong B, Praseena K. Effect of brown rice, white rice, and brown rice with legumes on blood glucose and insulin responses in overweight Asian Indians: a randomized controlled trial. Diabetes Technol Ther. 2014;16(5):317-25. https:/doi.org/10.1089/dia.2013.0259.

29. Osaretin A, Ebuehi T, Oyewole AC. Effect of cooking and soaking on physical characteristics, nutrient composition and sensory evaluation of indigenous and foreign rice varieties in Nigeria. Afr J Biotechnol. 2007;6(8): 1016-20.

30. Ayinde I, Raheem R, Hodefe O, Bakare H. Consumption pattern of ofada rice among civil servants in Abeokuta Metropolis of Ogun State, Nigeria. J Biol Agric Healthc. 2013;3(6):106-12

31. Champe PC, Harvey RA. Lippincott's Illustrated Reviews of Biochemistry. 2nd ed. USA: Lippincott-Raven Publishers Inc; 1994. p. 228-32.

32. Becker GA. Theory of the allocation of time. Econ J. 1965;75:493-517.

33. Grossman M. On the concept of health capital and the demand for health. J Polit Econ. 1972:80(2):223-55

34. Yen ST, Douglass SW, Yuan Y. Cigarette smoking and self-reported health in China. China Econ Rev. 2010;21(4):532-43.

35. Ormond, G. Alcohol income and health: a complicated but desirable mix. PhD Thesis. Republic of Ireland: University College Cork; 2014

36. Brookhart A, Rassen J, Schneeweiss S. Instrumental variable methods in comparative safety and effectiveness research. Pharmacoepidemiol Drug Saf. 2010;19(6):537-54.

37. Asfaw A, Mark C, Pana-Cryan R. Profitability and occupational injuries in U.S. underground coal mines. Accid Anal Prev. 2013;50:778-86.

38. Smith RJ, Blundell RW. An exogeneity test for a simultaneous equation tobit model with an application to labour supply. Econometrica. 1986;54(3):67985

39. Erhabor POI, Ojogho O. Demand analysis for rice in Nigeria. J Food Technol. $2011 ; 9(2): 66-74$

40. Ogunleke AO, Baiyegunhi LJS. Households' acceptability of local (ofada) rice based on quality attributes in south-west, Nigeria. Br Food J. 2019;121(9): 2233-48.

41. Kempen EL, Muller H, Symington E, van Eeden T. A study of the relationship between health awareness, lifestyle behaviour and food label usage in Gauteng. S Afr J Clin Nutr. 2012;25:15-21.

42. Jacobs SA, de Beer $\mathrm{H}$. Adult consumers' understanding and use of information on food labels: a study among consumers living in the Potchefstroom and Klerksdorp region. Public Health Nutr. 2010;14(3):1-13.

43. Wiles, N.L. The Use and Interpretation of the Nutrition Information on the Food Label of Selected Fat Spreads by Female Consumers Aged 25-45 Years, Living in Pietermaritzburg. University of KwaZulu-Natal, Pietermaritzburg. 2006; 86p. (Mini-dissertation - M. Science in Dietetics)

44. Variyam JN, Blaylock J, Smallwood D. Modelling Nutrient Intake: The Role of Dietary Information. Food and Consumer Economics Division, Economic Research Services, United States Department of Agriculture. Technical Bulletin, 1995; No.1842

45. Wardle J, Steptoe A, Oliver G, Lipsey Z. Stress, dietary restraint and food intake. J Psychosom Res. 2000;48(2):195-202.

46. Demont M, Ndour M. Upgrading rice value chains: experimental evidence from 11 African markets. Glob Food Sec. 2015:5:70-6.

47. Pro-poor Opportunities in Commodity and Service Markets Project (PrOpCom). Consumer survey on improved packaging and presentation on Ofada rice. Research International Market Trends, Monograph Series, 2009; Vol. 43.

48. Tomlins K, Manful J, Gayin J, Kudjawu B, Tamakloe I. Study of sensory evaluation, consumer acceptability, affordability and market price of rice. J Sci Food Agric. 2007;87:1564-75

49. Naseem A, Mhlanga S, Diagne A, Adegbola PY, Midingoyi GS. Economic analysis of consumer choices based on rice attributes in the food markets of West Africa: the case of Benin. Food Secur. 2013;5:575-89.

50. Loureiro ML, Nayga RM Jr. Physician's advice affects adoption of desirable dietary Behaviours. Rev Agric Econ. 2007;29(2):318-30.

\section{Publisher's Note}

Springer Nature remains neutral with regard to jurisdictional claims in published maps and institutional affiliations. 